\title{
Beszámoló az időskori törékenység megelőzését célzó ADVANTAGE Együttes Fellépés első találkozójáról az Európai Bizottság sajtóközleménye ${ }^{1}$ alapján
}

\author{
Report based on the European Commission's Press Release on the \\ Kick-off Meeting of ADVANTAGE Aiming to Prevent Frailty
}

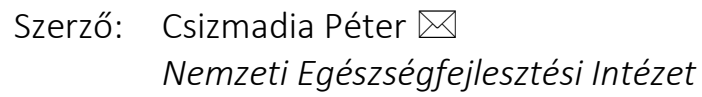

Beküldve: 2017.02.07.

doi: 10.24365/ef.v58i1.137

Kulcsszavak: időskori törékenység, egészséges idősödés

Keywords: frailty, healthy ageing

2017. január 19-20-án az ADVANTAGE Együttes Fellépés ünnepélyes keretek között megtartotta első találkozóját Madridban.

Összesen 64 résztvevő volt jelen 22 tagállam, és a konzorciumot alkotó több mint 40 szervezet képviseletében. Rajtuk kívül, több uniós finanszírozású projekt meghívottai mellett az Európai Bizottság is képviseltette magát az Egészségügyi és Élelmiszerbiztonsági Főigazgatóság (DG SANTE) és a Fogyasztó-, Egészség- és Élelmiszerügyi Végrehajtó Ügynökség (CHAFEA) révén.

Martin Seychell a DG SANTE főigazgató helyettese, és Elena Andradas a Spanyol Egészségügyi, Szociális és Esélyegyenlőségi Minisztérium Népegészségügyi, Minőségügyi és Innovációs főigazgatója köszöntötte a hallgatóságot a hivatalos megnyitón. Mindketten hangsúlyozták a társadalmunkban jelentkező demográfiai változások jelentőségét, valamint, hogy ez a közös munka kulcsfontosságú az időskori korlátozottsággal együtt járó legfőbb állapot, a törékenység kezelésében európai szinten. A két nap során a résztvevők aktívan részt vettek az együttes fellépés fő céljainak megvitatásában és megegyeztek a gyakorlati megvalósítást érintően a projektirányítás, szakmai tartalmak, eljárásrend és határidők kérdéseiben.

Ez az első együttes fellépés az időskori törékenység megelőzésére az Európai Unió harmadik Európai Egészségprogramjának (2014-2020) társfinanszírozásában, amelynek időtartama 3 év, költségvetése 3.500 .000 euró. 22 tagállam és több mint 40 szervezet vesz részt benne. Az együttes fellépést Spanyolország a Madrid Health Service-Getafe Hospital révén koordinálja a Spanyol Egészségügyi, Szociális és Esélyegyenlőségi Minisztérium támogatásával.

A munka, amely ezzel az összejövetellel kezdődött, különösen aktuális Európában, mivel a demográfiai változásokkal együtt járó, a szociális és egészségügyi ellátás iránti megnövekvő igényekre irányul, amelyek a krónikus megbetegedések, az időskori törékenység, a fogyatékosság és az időskor okozta terhekből erednek. Ezek a témák prioritásnak számítanak az Európai Unióban és a tagállamokban.

A projekt fő eredménye egy közös európai modell kialakítása lesz az időskori törékenység kezelésére, 
amely a stratégiai döntések megalapozását szolgálja majd a diagnózis, a kezelés és az ezzel kapcsolatos képzések, a fogyatékosság és a multi-morbiditás területén; valamint ellensúlyozza a korlátozottság és a krónikus megbetegedések okozta növekvő terhekből adódó fokozott igényt az egészségügyi ellátás iránt. A projekt hozzá fog járulni az idősek ellátásának a hatékonyabbá tételéhez, beleértve a nemek közötti különbségekből adódó szempontokat, a jobb ellátás tervezését, az ellátások összehangolását, az innovatív szervezeti megközelítések ösztönzését, a jobb együttműködést a szakmai és informális gondozás között, valamint az önálló életvitel támogatását.

Az együttes fellépés épít a korábbi tevékenységek eredményeire, például az Európai Innovációs Partnerség az Aktív és Egészséges Időskorért (European Innovation Partnership on Active and Healthy Ageing, EIP-AHA) munkájára, különösképpen annak A3 akciócsoportja által az időskori törékenység megelőzésére kidolgozott eredménytermékekre és bevált jó gyakorlatokra, valamint az Európai Bizottságnak az Európai Unióban végbemenő demográfiai változásokra adott válaszként 2012-ben megkezdett tevékenységére.

\footnotetext{
${ }^{1}$ PRESS RELEASE COMMUNICATION NOTE. ACTION ON FRAILTY PREVENTION POLICY IN EUROPE STARTED in ADVANTAGE KICK-OFF. http://www.promisalute.it/upload/mattone/documentiallegati/communicationpostkickoffADVANTAGE30012017 13660 2490.pdf (Elérve: 2017.02.22.)
}
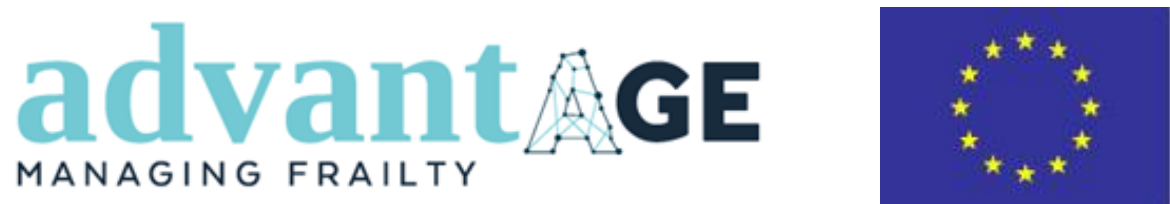

Co-funded by the Health Programme of the European Union 